\title{
Dietary fibre, ischaemic heart disease and diabetes mellitus
}

\author{
By Hugh Trowell, * Department of Medicine, Makerere University, Uganda
}

\section{Definition of dietary fibre}

Dietary fibre is defined as the remnants of vegetable cell walls which are not hydrolyzed by alimentary enzymes of man (Trowell, $1972 a, b$; Cummings, 1973). Dietary fibre appears to be identical with unavailable carbohydrate (celluloses and hemicelluloses) and lignin (Southgate, I969). Food tables do not report the constituents of dietary fibre by direct analysis; crude fibre must therefore serve as an indicator of dietary fibre and be used to test provisionally the two following hypotheses.

\section{First hypothesis : dietary fibre protects against ischaemic heart disease (IHD)}

The prevalence of IHD was recently investigated in II54 age-matched Irish brothers, during one study in Ireland and the other in Boston, Massachusetts (Brown, Bourke, Gearty, Finnegan, Hill, Heffernan-Fox, Fitzgerald, Kennedy, Childers, Jessop, Trulson, Latham, Cronin, McCann, Clancy, Gore, Stoudt, Hegsted \& Stare, I 970). Only $29 \%$ of all deaths in Ireland in men aged $45^{-6} 4$ years were the result of IHD, compared with $42 \%$ of all deaths in second-generation Americans in Massachusetts. This decreased incidence of IHD in Ireland was confirmed by a study of coronary arteries and aortas obtained from autopsies in Ireland; in these samples atheromatous changes occurred later and were less severe than in those obtained in Boston.

The clinical survey produced electrocardiographic evidence of IHD in $2 \cdot 1 \%$ of Irish brothers compared with $4.0 \%$ of Boston brothers; therefore the Irish study revealed about half as much IHD as the Americans. The mean serum cholesterol level was $2.13 \pm 0.44 \mathrm{~g} / 1$ in the Irish brothers compared with $2 \cdot 19 \pm 0.39 \mathrm{~g} / \mathrm{l}$ in the Boston brothers. This was surprising as Irish brothers ate slightly more total fat and more animal fat (Table I) and slightly less polyunsaturated fat. Full details were given of the amount of the various types of fat. So much evidence has been produced concerning the role of fat, especially saturated animal fat, in increasing serum cholesterol levels and both the atheromatous changes in coronary arteries and the prevalence of IHD, that the absence of any correlation in this investigation suggested that other factors also operated. The intake of sugar, protein and cholesterol, also cigarette smoking and alcohol consumption, appeared very similar in the two groups, as were the blood pressures.

*Present address: Woodgreen, Fordingbridge SP6 zAZ, Hampshire. 
'Table I. Composition of diet in Ireland-Boston heart study

(Brown et al. 1970)

(Mean values for determinations)

\begin{tabular}{|c|c|c|c|c|c|c|c|}
\hline & \multicolumn{2}{|c|}{ Energy } & \multicolumn{2}{|c|}{ Fat } & \multicolumn{3}{|c|}{ Carbohydrate } \\
\hline & $(\mathrm{MJ} / \mathrm{d})$ & $\mathrm{kcal} / \mathrm{d}$ & $\begin{array}{l}\text { Total } \\
\text { (g/d) }\end{array}$ & $\begin{array}{c}\text { (g animal } \\
\text { fat } / \mathrm{kg} \text { ) }\end{array}$ & $\begin{array}{l}\text { Sugar } \\
\text { (g/d) }\end{array}$ & $\begin{array}{l}\text { Starch } \\
(\mathrm{g} / \mathrm{d})\end{array}$ & $\begin{array}{l}\text { Fibre } \\
(\mathrm{g} / \mathrm{d})\end{array}$ \\
\hline Ireland & 15.8 & 3768 & 159 & 90 & 134 & 267 & $6 \cdot 4$ \\
\hline Boston & 12.9 & 3075 & 135 & 84 & ז 33 & тा 6 & 3.6 \\
\hline
\end{tabular}

The investigators emphasised that body-weight was lower and skinfold measurements smaller in Irish brothers who ate food with a higher energy content $(2 \mathrm{I} \%$, chiefly as starch) and a higher fat content. Irish brothers ate $267 \mathrm{~g}$ starch/d (28\% dietary energy) compared with II $6 \mathrm{~g} / \mathrm{d}$ ( $15 \%$ dietary energy) eaten by Boston brothers. Starch was derived from cereal products, particularly wheat flour, and potatoes. The Irish nation consume $170 \%$ more potatoes than Americans and $30 \%$ more cereal products, mainly white flour. Americans, at the national level, eat $\mathrm{I} 45 \%$ more vegetables and $89 \%$ more fruit than the Irish. The problem posed by this study of Irish and Boston brothers resolved itself into a consideration of the asssociation between increased physical activity in Ireland, especially in rural occupations, and maintainance of normal body-weight with increased intake of energy (starch and fat). Very strenuous but not moderate physical exercise offers some protection against IHD but does not reduce serum cholesterol levels (Morris, Chave, Adam, Sirey, Epstein \& Sheehan, I973). The lower level of serum cholesterol in the Irish brothers remains unexplained. It is suggested that protection against hyperlipidaemia, IHD and obesity was provided for Irish brothers by increased intake of crude fibre, $78 \%$ more than the Americans. Antar \& Ohlson (1965) reported that large amounts of potato given in experimental diets significantly reduced serum cholesterol levels in man. They postulated but did not develop the hypothesis that fibre might be protective. Small amounts of potato proved less effective (Grande, 1967).

\section{Experiments with plant cell-wall polysaccharides}

Cell-wall polysaccharides present in fibre are hypocholesterolaemic in certain animals; pectin has proved effective in animals (Fisher \& Griminger, 1967) and in man (Keys, Grande \& Anderson, 196r). Large doses of cellulose reduced serum cholesterol levels in cholesterol-fed volunteers and increased bile-salt excretion (Shurpalekar, Doraiswamy, Sundaravalli \& Rao, I971). Many mucilaginous polysaccharides have proved hypocholesterolaemic in cockerels (Fahrenbach, Riccardi \& Grant, 1966), scleroglucan was effective in chicken (Griminger \& Fisher, 1966) and polysaccharides from seaweeds were effective in rats (Iritani \& Nogi, 1972). Konnyaku powder, a Japanese foodstuff rich in glucomannans, was hypolipidaemic in rats, partly by decreasing cholesterol absorption (Kiriyama, Okazaki \& Yoshida, I969). Natural foodstuffs rich in cell-wall polysaccharides, especially oats and oat hulls which contain $360 \mathrm{~g}$ crude fibre $/ \mathrm{kg}$ (Kent, 1970) were hypocholesterolaemic 
in chicken (Fisher \& Griminger, 1967). A bacterial polysaccharide, dextran (Ditzel \& Dyerburg, 1969) and a hydrophilic colloid of Blond Psyllium seeds (Forman, Garvin, Forestner \& Taylor, r968) also reduce serum cholesterol levels. Wheat straw, even peat, have displayed similar activity (Moore, 1967). The hypocholesterolaemic properties of fibre-rich leguminous seeds and whole cereals and the increased excretion of bile salts (Heaton, 1972) in the diet of animals and man has been reviewed by Trowell $(1972 a, c)$. Fibre from fruit and vegetables has not been shown to have this effect in animals or man, but this substance has rarely been tested; it contains less hemicellulose than whole cereals.

Second hypothesis : prolonged consumption of fibre-depleted starch is conducive to the development of diabetes mellitus in susceptible genotypes

In England and Wales death rate associated with diabetes/million women increased steadily from 120 in 193 I to 153 in 1940 . In 194I, the 'diabetes' death rate in women started to decrease steeply to reach the lowest level of the present century, 86 , in 1954 (Table 2); it remained fairly stationary between 1955 and 1959 but subsequently increased steadily to Ir 8 in 1970 (Registrar General, r86r-1970). From 1939 recorded deaths from diabetes signified deaths of diabetic persons from any cause; most die from IHD or some vascular complications.

'Table 2. 'Diabetes' mortality rates for women in England and Wales, 1939-46, 195056, and composition of diet (Registrar General, 1861-1970; Frazer, 1958; Board of Trade, 1968; Robertson, 1972)

(Approximate mean content of crude fibre in wheat flour and mean intakes of food for each year)

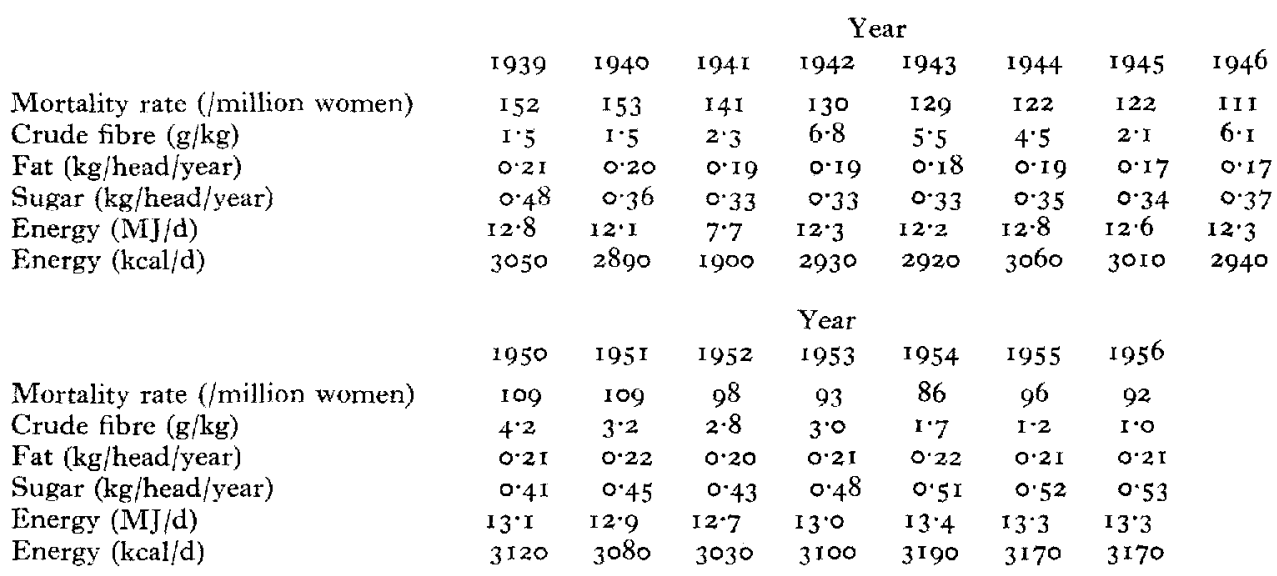

To identify the factor, or factors, which accompanied and possibly aided this remarkable reduction in mortality rates, the time sequence of events must be identified. Faced with a probable shortage of imported wheat, the flour-milling extraction rate was raised from $70-72 \%$ (pre-war level, fibre $1 \cdot 5 \mathrm{~g} / \mathrm{kg}$, (Robertson, I972)) and $73 \%$ in October 1939 to $75 \%$ on 28 April I94I, but there was no significant increase in the fibre content as a result of these changes. However, on 23 
January I94I the second Medical Research Council memorandum on bread had strongly recommended $85 \%$ national flour extraction, and on $3 \mathrm{I}$ May r94I it was announced that government had already decided to make this generally available (Medical Research Council, r94I). Millers co-operated and, between late r94I and early I 942, 303 samples of flour were analysed. These revealed much variation in the fibre content, with values of $4^{-I} 3 \mathrm{~g} / \mathrm{kg}$, the mean value was not reported, but the median was $7.0 \mathrm{~g} / \mathrm{kg}$ and the mode (the most frequently occurring observation) was $8 \mathrm{~g} / \mathrm{kg}$ (Research Association of British Flour Millers, 1942). The previously recommended, but optional, extraction rate of $85 \%$ eventually became compulsory on 23 March 1942 , but it was some time before machinery could be altered to ensure that the fibre content of this high-extraction flour could be kept as low as possible, a point specifically recommended by medical advisors on many occasions. In November 1942 it was reported that the fibre content of the $85 \%$-extraction flour had varied less than that in flour sampled in the period in which the $85 \%$ extraction rate had been optional and that 322 flour samples received had a mean fibre content of $7 \mathrm{~g} / \mathrm{kg}$ ( $\mathrm{sD}$ not calculated). It was reported that the national mean fibre content was decreasing (Scientific Adviser, Ministry of Food, 1942). Various high extraction rates (80-90\%) were used between 1942 and 1953 (Horder, Dodds \& Moran, r954; Robertson, 1972). In August I953, 'National' flour was no longer compulsory, it remained as an optional flour, but sales dwindled in 1954 and it ceased to be milled in September 1956; its place had been taken progressively by the more popular white flour, which had a $70 \%$ extraction rate, from August 1953 (Frazer, 1958).

The results of one investigation have indicated that a reduction of fat, or energy or some associated substances might have been a causative factor in deaths from diabetes (Himsworth, 1949). Fat consumption decreased by $8.5 \%$ in 1940 but the mortality rate was still increasing; fat intake exceeded pre-war levels in $195^{\circ}$, I 951 and 1954 but the mortality rate continued to decrease. Maturity-onset diabetes improves if energy intake is reduced considerably, but energy intake decreased by $5 \%$ only in 1940 , this value was more than in any subsequent year and mortality rates were still increasing; energy intake exceeded the pre-war level in $1944,195^{\circ}$, I953 and I954, but mortality rates continued to decrease. Sugar may have been a causative factor (Cleave, Campbell \& Painter, 1969), but sugar intake decreased by $25 \%$ in 1940 while the mortality rate was still increasing. Sugar intakes were approximately the same as pre-war values in 1953 , exceeding these values in 1954 , but the mortality rate continued to decrease (Board of Trade, 1968). One factor alone, the extraction rates of the flour and its fibre content, followed the same pattern as the complex sequence of events. However, a more detailed study is required as the relationship between extraction rates and fibre content is not constant under the difficulties imposed by war or peace (Frazer, I958). High extraction rates increase the amounts of many food nutrients, including biotin and magnesium; also there was an increased consumption of all grain products and vegetable protein between $194^{\circ}$ and 1952. It must be emphasised that when there was maximum increase in the crude-fibre content of wheat flour (1941 and 1942) and the highest extraction rate $(90 \%$ for a short time in 1946$)$ there were three of the largest reductions in 
'diabetes' mortality rates (I94I-1954). Conversely when the crude-fibre content of wheat flour decreased greatly, as in 1943 and 1945, the 'diabetes' mortality rate decreased little or remained stationary.

In England during World War I (1914-19I8) the extraction rate had been $70 \%$ until in November 1916 it was officially raised to $76 \%$ and in February 1917 to $8 \mathrm{I} \%$ and early in $19 \mathrm{I} 8$ to $90 \%$ but at the end of that year it reverted to $70 \%$ (McCance \& Widdowson, 1956). 'Diabetes' mortality rate in females had increased from $86 /$ million in 1900 to $120 /$ million in 1915 , it decreased to $114 /$ million in $1916,96 /$ million in 1917 , and $90 /$ million in 1918 , but increased to $100 /$ million in 1919 , and then to $153 /$ million in 1940 (Registrar General, 1900-1940). Mortality rate in males decreased slightly but its significance was difficult to evaluate, as the war was associated with many changes among men.

\section{Other suggestions}

In a study of Cape Town Bantu who ate $6.5 \mathrm{~g}$ fibre/d (A. R. P. Walker, personal communication) $3.6 \%$ diabetic-type glucose-tolerance tests (GTT) were abtained, but with rural Transvaal Bantu who ate $24.8 \mathrm{~g}$ fibre/d (Trowell, I972c) $0.05 \%$ diabetic-type GTTs were obtained (Marine, Vinik, Edelstein \& Jackson, I969; Swanepoel, Campbell, Goldberg \& Jackson, r971). In the Yemen, Jews who had eaten large amounts of wholemeal bread showed a low incidence of diabetes but this increased after emigration and 20 years' residence in Israel (Cohen, I96r; Cohen, Bavly \& Poznanski, I961).

A survey of the literature on the experimental production of diabetes and obesity in small rodents reveals little evidence that either of these conditions is produced if dietary fat alone in moderate amount, $10 \%$ energy, is added to any diet eaten ad lib. These are examples of different rodents, either from arid, hot regions where their foodstuffs were rich in fibre or bred in the laboratory, all were fed on low-fibre $(20 \mathrm{~g} / \mathrm{kg})$, moderate-fat $(100 \mathrm{~g} / \mathrm{kg})$ diets until they developed obesity and hyperglycaemia, even diabetes, neither condition developed with high-fibre $(5 \circ \mathrm{g} / \mathrm{kg})$, low-fat $(3 \circ \mathrm{g} / \mathrm{kg})$ diets fed ad lib. (Gleason, Lauris \& Soeldner, I967), or when the wild rodents were fed $a d l i b$. on fibre-rich vegetables rather than on carbohydraterich laboratory food ad lib. (Schmidt-Nielsen, Haines \& Hackel, I964). Similarly in GTT's the blood glucose level after $\mathrm{I}$ h $(970 \mathrm{mg} / \mathrm{l})$ was much lower in rats given fibre-rich millet (Eleucine coracana) ( $3^{\circ} \mathrm{g}$ fibre $/ \mathrm{kg}$ ) than in those given refined wheat flour ( $\mathrm{r} \cdot \mathrm{g}$ fibre $/ \mathrm{kg}$ ) when the blood glucose level was $\mathrm{I} \cdot 35 \mathrm{~g} / \mathrm{l}$ (Vijayagopalan $\&$ Kurup, 1972; P. A. Kurup, personal communication).

In studies with known laboratory foods, e.g. Purina chow, or natural foods, e.g. tapioca starch, the crude fibre content is not generally reported, but these diets contain carbohydrates which are fibre-depleted and produce hyperglycaemia (Vijayagopalan \& Kurup, I970) and diabetes (Kramer, Liberman, Soeldner \& Gleason, I969) in rodents. Fasting blood-glucose concentrations and oral GTT curves were significantly lower in Africans who ate large amounts of lightly-processed maize $(270 \mathrm{~g} / \mathrm{d})$ and little fat $(35 \mathrm{~g} / \mathrm{d})$ than in African students who took their starch largely as white bread ( $120 \mathrm{~g} / \mathrm{d}$ ) and had more fat $(9 \circ \mathrm{g} / \mathrm{d})$, and there were con$32(3) 3$ 
comitant changes in serum-insulin levels (Wapnick, Wicks, Kanengoni \& Jones, I972). In communities in which large amounts of natural starch were eaten the I $h$ peak of the GTT curve showed little increase with age, in contrast to the pattern scen in the Western world (Goldrick, Sinnett \& Whyte, 1970).

\section{Obesity}

Investigators in the Ireland-Boston heart survey considered that increased physical activity protected the Irish against obesity and IHD, although the energy intake was higher (Brown et al. 1970). It may be postulated that increased physical activity and increased consumption of starch from fibre-rich potatoes may result in slightly decreased absorption (Southgate \& Durnin, 1970) but increased sensations of satiety from increased amounts of unabsorbed protein and fat and unavailable carbohydrate in the gut, thus providing the physiological basis for the control of non-obese body-weight.

This work was carried out with the aid of a grant from the British Heart Foundation.

\section{REFERENCES}

Antar, M. A. \& Ohlson, M. A. (1965). F. Nutr. 85, 329.

Board of Trade (1968). Board of Trade $\mathcal{F}$. 194, 753 .

Brown, J., Bourke, G. J., Gearty, G. F., Finnegan, A., Hill, M., Heffernan-Fox, F. C., Fitzgerald, D. E., Kennedy, J., Childers, R. W., Jessop, W. J. E., Trulson, M. F., Latham, M. C., Cronin, S., McCann, M. B., Clancy, R. E., Gore, l., Stoudt, H. W., Hegsted, D. M. \& Stare, F. J. (1970). Wld Rev. Nutr. Diet. 12, I.

Cleave, T. L., Campbell, G. D. \& Painter, N. S. (1969). Diabetes, Coronary Thrombosis and the Saccharine Disease p. I5. Bristol: John Wright.

Cohen, A. M. (196r). Metabolism ro, 50.

Cohen, A. M., Bavly, S. \& Poznanski, R. (1961). Lancet ii, 1399.

Cummings, J. (1973). Gut (In the Press.)

Ditzel, J. \& Dyerburg, J. (1969). F. Atheroscler. Res. 10, 5.

Fahrenbach, M. J., Riccardi, B. A. \& Grant, W. C. (1966). Proc. Soc. exp. Biol. Med. 123, 321.

Fisher, H. \& Griminger, P. (1967). Proc. Soc. exp. Biol. Med. 126, 108.

Forman, D. T., Garvin, J. E., Forestner, J. E. \& Taylor, C. B. (1968). Proc. Soc. exp. Biol. Med. 127, I 060 .

Frazer, J. R. (1958). F. Sci. Fd Agric. 9, I 25.

Gleason, R. E., Lauris, V. \& Soeldner, J. S. (1967). Diabetologia 3, 175 .

Goldrick, R. B., Sinnett, P. F. \& Whyte, H. M. (1970). In Atherosclerasis, Proceedings of the Second International Symposium p. 366 [R. J. Jones, editor]. New York: Springer-Verlag.

Grande, F. (1967). Am. F. clin. Nutr. 20, 176.

Griminger, P. \& Fisher, H. (1966). Proc. Soc. exp. Biol. Med. 122, $55 \mathrm{I}$.

Heaton, K. W. (1972). Bile Salts in Health and Disease p. 184. Edinburgh: Churchill Livingstone.

Himsworth, H. P. (i949). Proc. R. Soc. Med. 42, 323.

Horder, Lord, Dodds, C. \& Moran, T. (1954). Bread p. 170. London: Constable.

Iritani, N. \& Nogi, J. (1972). Atherosclerosis 15, 87.

Kent, N. L. (1970). Technology of Cereals p. 224. Oxford: Pergamon Press.

Keys, A., Grande, F. \& Anderson, J. 'T'. (I961). Proc. Soc. exp. Med. Biol. ro6, 555.

Kiriyama, S., Okazaki, Y. \& Yoshida, A. (1969). F. Nutr. 97, 382.

Kramer, M. W., Liberman, D. F., Soeldner, J. S. \& Gleason, R. E. (1969). Diabetologia 5, 353.

McCance, R. A. \& Widdowson, E. M. (1956). Breads, White and Broz'n p. 59, London: Pitman.

Marine, M., Vinik, A. I., Edelstein, I. \& Jackson, W. P. U. (1969). Diabetes 18, 840 .

Medical Research Council (194I). Br. med. F. i, 828 .

Moore, J. H. (1967). Br.F. Nutr. 2I, 207.

Morris, J. N., Chave, S. P. W., Adam, C., Sircy, C., Epstein, L. \& Sheehan, D. J. (1973). Lancet i, 333. 
Registrar General (186r-1970). Statistical Review of England and Wales, Part I, Medical Tables London: H.M. Stationery Office.

Research Association of British Flour Millers (x942). Nature, Lond. 149, 460.

Robertson, J. (1972). Nature, Lond. 238, 290.

Schmidt-Nielsen, K., Haines, H. B. \& Hackel, D. B. (1964). Science, N.Y. 143, 689.

Scientific Adviser, Ministry of Food (1 942). Nature, Lond. 150, 538.

Shurpalekar, K. S., Doraiswamy, T. R., Sundaravalli, O. E. \& Rao, M. N. (1971), Nature, Lond. 232, 554 .

Southgate, D. A. T. (1969), F. Sci. Fd Agric, 20, 331.

Southgate, D. A. T. \& Durnin, J. V. G. A. (I970). Br. F. Nutr. 24, 517.

Swanepoel, H., Campbell, G. D., Goldberg, M. \& Jackson, W. P. U. (r971). In Diabetes in Asia p. 3 [S. 'Tsuji and M. Wada, editors]. Amsterdam: Excerpta Medica.

Trowell, H. (1972a). Revue Etud. clin. biol. 17, 345 .

Trowell, H. (1972b). Atherosclerosis r6, 138 .

Trowell, H. (1972c). Am. F. clin. Nutr. 25, 926.

Vijayagopalan, P. \& Kurup, P. A. (1970), Atherosclerosis II, 257.

Vijayagopalan, P. \& Kurup, P. A. (1972). Atherosclerosis 16, 247.

Wapnick, S., Wicks, A. C. B., Kanengoni, E. \& Jones, J. J. (1972). Lancet ii, 300. 